\title{
Hambatan Ekspor Crude Palm Oil (CPO) Indonesia ke Uni Eropa pasca Kebijakan Renewable Energy Directive (RED)
}

\author{
Jevon Natashya T. \\ Undergraduate Student of International Relations Department at \\ Parahyangan Catholic University \\ jevonnats@gmail.com
}

\begin{abstract}
Beside Malaysia, Indonesia is also one of the largest Crude Palm Oil (CPO) producer and exporter in the world. European Union is one of Indonesia's trading partner and the biggest importer of CPO that used for the biofuel production, especially the biodiesel for transportation sector. But, in 2009, European Union released the Renewable Energy Directive (RED) that required all members to used renewable energy for every sector with the minimum requirement $20 \%$ for general sectors and $10 \%$ for transportation sectors. While this policy will make the European Union countries used the clean energy, RED became a new kind of NonTariff barriers for Indonesia's CPO that become an important commodity from Indonesia. This paper will explain by the theory of International Political Economy (IPE) by focused into the Neo-Mercantilism to the analysis of Non-Tariff barriers that used by European Union for the CPO import into Indonesia. Besides that, the writer also used a National Interest concept to explain the importance of CPO for Indonesia and European Union Countries that agreed with the RED.
\end{abstract}

Keywords: Indonesia, Crude Palm Oil (CPO), Renewable Energy Directive (RED), Neo-Merchantilism, European Union, Non-Tariff Barriers.

\section{Pendahuluan}

ISSN 0216-5031

Copyright @ 2018 Universitas Katolik Parahyangan 


\section{Jurnal Sentris KSMPMI Vol. 2 - 2019}

Berakhirnya Perang Dingin yang ditandai dengan globalisasi, perkembangan teknologi, serta berkembangnya kerjasama antar-negara menyebabkan pergeseran isu dalam studi Hubungan Internasional dan berkembangnya aktor-aktor non-negara, seperti Transnational Corporations (Microsoft, McDonalds, dan Nestle), International Finance Institutions (Bank Dunia dan International Monetary Fund), dan Organisasi Regional (NAFTA, MERCOSUR, African Union, dan Uni Eropa). ${ }^{1}$ Selain itu, United Nations Development Program (UNDP) Report tahun 1994 meredefinisikan pemahaman studi keamanan dengan masukkan berupa isu-isu keamanan non-tradisional, khususnya yang terkait dengan kemanusiaan. Dalam laporan yang sama, dijelaskan bahwa aktor-aktor non-negara dapat menunjukkan peranannya dalam penyelesaian isu keamanan. ${ }^{2}$

\section{Selain 1994 United Nations Development Program (UNDP)} Report, perkembangan isu keamanan yang bersifat non-tradisional turut dipengaruhi oleh disrupsi lingkungan terhadap sistem kehidupan manusia yang mengakibatkan krisis dan kelangkaan sumber daya. Permasalahan ini dianggap krusial karena perubahan iklim merupakan potensi konflik baru bagi dunia akibat meningkatnya jumlah pengungsi karena kekurangan pangan dan kelangkaan SDA di negaranya. Maka dari itu, Dalby mengungkapkan bahwa environmental security telah menjadi pembahasan

\footnotetext{
${ }^{1}$ Jeffrey Haynes, Peter Hough, Shahin Malik, and Lloyd Pettiford, World Politics (Oxon: Routledge, 2013), h. 92-97.

${ }^{2}$ Pauline Kerr, "Human Security," dalam Contemporary Security Studies, Third Edition, ed. Alan Collins (Oxford: Oxford University Press, 2013), h. 104-106.
}

ISSN 0216-5031

Copyright (C) 2018 Universitas Katolik Parahyangan 


\section{Jurnal Sentris KSMPMI Vol. 2 - 2019}

penting dalam studi Hubungan Internasional. ${ }^{3}$ Di samping itu, permasalahan lingkungan berdampak pada fluktuasi harga dan gangguan ketersediaan SDA berbasis energi di dunia. Bahkan, terdapat prediksi bahwa di tahun 2040 dunia akan mengalami krisis terkait dengan bahan bakar fosil, khususnya minyak bumi dan gas alam yang merupakan sumber energi terbesar yang digunakan oleh masyarakat dunia. Hal ini menunjukkan keterkaitan antara permasalahan lingkungan dengan ketahanan energi dunia. ${ }^{4}$

Penjelasan di atas merupakan alasan bahwa keamanan yang bersifat non-tradisional menjadi pembahasan penting dalam tatanan global, khususnya isu lingkungan yang memiliki keterkaitan langsung dengan ketahanan energi global. Dalam penelitian yang dilakukan oleh Hiscock, cara terbaik dalam mengatasi krisis energi global adalah melakukan pengembangan Energi Baru dan Terbarukan (EBT), yang telah dikembangkan dalam berbagai bentuk, antara lain: panel solar (Jepang dan Jerman), hydropower (Brazil dan Tiongkok), dan panas bumi (Islandia). Bahkan, Saudi Arabia sebagai negara penghasil minyak bumi terbesar pun berusaha mengembangkan hydropower. ${ }^{5}$ Penggunaan EBT sendiri bertujuan untuk memenuhi kebutuhan listrik, pemanas ruangan, bahan

\footnotetext{
${ }^{3}$ Simon Dalby, "Climate Change and Environmental Security," dalam Security Studies: An Introduction, Second Edition, ed. Paul D. Williams (Oxon: Routledge, 2013), h. 312 313.

${ }^{4}$ Bernice Lee, Felix Preston, Jaakko Kooroshy, Rob Bailey, and Glada Lahn (Chatnam House), Resources Futures: A Chatham House Report (London: The Royal Institute of International Affairs, 2012), h. 2 \& 12.

${ }^{5}$ Geoff Hiscock, Earth Wars: The Battle for Global Resources (Singapore: Wiley, 2012), h. 124-125, 133.
} 
Jurnal Sentris KSMPMI Vol. 2 - 2019

bakar, industri, dan mengurangi dampak perubahan iklim akibat tingginya penggunaan bahan bakar fosil. ${ }^{6}$

Selain negara-negara tersebut, anggota Uni Eropa turut mengembangkan EBT secara signifikan. Pengembangan EBT di kawasan Uni Eropa sendiri mencakup beberapa bentuk, antara lain: hydropower, panas bumi, tenaga angin, panel solar, dan bioenergi (biofuel dan biogas). Sejak 1990 hingga 2017, Uni Eropa memiliki kecenderungan untuk menggunakan dan memproduksi EBT yang berbasis biofuel. EBT ini digunakan oleh negara-negara Uni Eropa guna memenuhi kebutuhan industri maupun pemenuhan bahan bakar alat transportasi (bus, truk, dan mobil pribadi). Sedangkan untuk memenuhi kebutuhan listrik, negaranegara di kawasan Uni Eropa telah memulainya dengan memanfaatkan hydropower sejak 1990 yang diikuti dengan perkembangan tenaga angin dan panel solar di akhir 1990-an. Swedia dan Finlandia telah mengembangkan transporasi berbasis energi terbarukan dengan pemakaian di tahun 2017 mencapai lebih dari 35\% untuk Swedia dan lebih dari $15 \%$ untuk Finlandia. ${ }^{7}$

Tingginya penggunaan bioenergi di kawasan Uni Eropa menyebabkan adanya ketergantungan akan impor CPO asal Indonesia. CPO sendiri digunakan sebagai bentuk energi alternatif dalam transportasi, industri pangan, industri non-pangan, dan industri rumah tangga. ${ }^{8}$

\footnotetext{
${ }^{6}$ United States Department of Energy, Renewable Energy: An Overview (Golden, Colorado: National Renewable Energy Laboratory (NREL), 2001), h. 1.

${ }^{7}$ European Commission (EC) - Eurostat, Renewable Energy Statistic: Statistics Explained (Brussels: European Union, 2019), h. 2-8.

${ }^{8}$ Douglas Sheil, The Impacts and Opportunities of Oil Palm in Southeast Asia (Jakarta: Center for International Forestry Research, 2009), h. 20.
} 


\section{Jurnal Sentris KSMPMI Vol. 2 - 2019}

Tingginya ketergantungan Uni Eropa terhadap bioenergi menyebabkan adanya kebutuhan akan CPO. Sayangnya, CPO yang berasal dari minyak sawit mentah ini hanya dapat tumbuh di negara-negara tropis. Maka dari itu, pada akhirnya, Uni Eropa harus melakukan impor dari negara lain, seperti Indonesia dan Malaysia. ${ }^{9}$

Peralihan penggunaan energi di kawasan Uni Eropa dalam bentuk EBT dimana salah satunya adalah penggunaan CPO untuk memenuhi kebutuhan biofuel dan biodiesel pada akhirnya menyebabkan Uni Eropa mengeluarkan kebijakan Renewable Energy Directive (RED) 2009/28/EC yang dikeluarkan per-tanggal 23 April 2009. Bagi Uni Eropa, RED bertujuan untuk meningkatkan ketahanan energi, mengurangi kadar gas emisi, dan melakukan peralihan terkait penggunaan bahan bakar fosil ke dalam bentuk EBT. Kebijakan ini berisi penetapan dan promosi terkait penggunaan EBT di kawasan Uni Eropa. RED sendiri mengatur bahwa anggota dari Uni Eropa harus menggunakan EBT dalam aspek transportasi minimal 10\% dan aspek lainnya (industri, rumah tangga, dan kebutuhan energi listrik) sebesar minimal 20\% pada tahun 2020. Angka awal ini diambil berdasarkan pada pencapaian yang dilakukan oleh sejumlah negara anggota melalui angka terendah sebesar 10\% (Malta) dan angka tertinggi sebesar $49 \%$ (Swedia). Selain penggunaan minimal EBT, RED turut mengatur kriteria penggunaan energi berbasi biofuel yang layak digunakan di kawasan Uni Eropa. Kriteria tersebut, antara lain: minim gas emisi, bersifat berkelanjutan, memperhatikan kelestarian lingkungan, dan

\footnotetext{
${ }^{9}$ Retno Ayu Debora M., "PENOLAKAN CRUDE PALM OIL (CPO) INDONESIA OLEH UNI EROPA" (Tesis Magister Ilmu Hubungan Internasional, Universitas Gadjah Mada, Yogyakarta, 2014), h. 2-3.
} 


\section{Jurnal Sentris KSMPMI Vol. 2 - 2019}

tidak merusak lahan perhutanan ataupun perkebunan negara setempat, khususnya dalam melakukan kegiatan produksi energi. ${ }^{10}$

Secara langsung, kebijakan RED mengakibatkan hambatan perdagangan CPO Indonesia ke Uni Eropa. Hal ini disebabkan oleh gagalnya Indonesia dalam memenuhi target minimal 35\% terkait dengan kelestarian lingkungan, sifat berkelanjutan, perlindungan hutan, dan perlindungan keanekaragaman hayati Indonesia. Keadaan ini pada akhirnya menyebabkan timbulnya hambatan perdagangan non-tarif yang diberlakukan oleh Uni Eropa terhadap Indonesia dalam bentuk hambatan ekspor. Adanya hambatan dagang mengakibatkan pembatasan ekspor CPO Indonesia ke Uni Eropa. Hambatan ini menyebabkan terjadinya pertentangan antara Indonesia, Uni Eropa, maupun World Trade Organization (WTO) akibat perbedaan kriteria terkait standarisasi penggunaan biofuel. $^{11}$

Terkait dengan permasalahan yang dipaparkan, penulis akan melakukan analisis terhadap adanya hambatan dagang yang dilakukan oleh Uni Eropa terhadap Indonesia dalam bentuk hambatan non-tarif berupa hambatan ekspor. Analisa akan dilakukan oleh penulis dengan menggunakan Teori Neo-Merkantilisme dalam menjelaskan hambatan dagang dan Konsep Kepentingan Nasional guna menjelaskan permasalahan serta kepentingan Indonesia maupun Uni Eropa dalam

\footnotetext{
${ }^{10}$ Andreas Lendle and Malorie Schaus, Sustainability Criteria in the EU Renewable Energy Directive: ICTSD Information Note No. 2, September 2010 (Geneva: International Center for Trade and Sustainable Development), h. 1-3.

${ }^{11}$ Gisa Rachma Khairunisa dan Tanti Novianti, "DAYA SAING MINYAK SAWIT DAN DAMPAK RENEWABLE ENERGY DIRECTIVE (RED) UNI EROPA TERHADAP EKSPOR INDONESIA DI PASAR UNI EROPA," Jurnal Agribisnis Indonesia Vol. 5 No. 2 (2017): 126.
} 
Jurnal Sentris KSMPMI Vol. 2 - 2019

hubungan dagang ini. Selain itu, teori dan konsep turut digunakan dalam membantu penulis dalam menganalisis paper guna menjawab pertanyaan penelitian berupa: "Bagaimana terjadinya hambatan ekspor Crude Palm Oil (CPO) Indonesia ke Uni Eropa pasca Kebijakan Renewable Energy Directive (RED) berjalan?."

\section{Kerangka Pemikiran}

Terkait dengan pemaparan tulisan ini, penulis menggunakan kerangka pemikiran berupa teori Neo-Merkantilisme dan konsep Kepentingan Nasional guna menjelaskan permasalahan terkait hambatan ekspor CPO Indonesia ke Uni Eropa pasca diterbitkannya kebijakan RED pada tahun 2009.

Neo-Merkantilisme merupakan salah satu pendekatan dalam Ekonomi Politik Internasional yang merupakan akar dari pendekatan Merkantilisme yang muncul pasca Perang Dunia II. Akan tetapi, pendekatan ini memiliki perbedaan yang cukup signifikan jika menakar pada aspek ekonomi. Merkantilisme adalah pendekatan yang dipopulerkan oleh Alexander Hamilton dan Friedrich List. Pendekatan ini menekankan pada kebijakan berbasis nasionalisme ekonomi guna mengembangkan industri dalam negeri yang bertujuan guna meningkatkan nilai ekspor serta mengurangi ketergantungan impor dalam suatu negara. Kebijakan ini pada akhirnya mengakibatkan terjadinya zero-sum game yang dilakukan dengan mengorbankan negara lain guna mencapai surplus ekonomi. Sedangkan, 


\section{Jurnal Sentris KSMPMI Vol. 2 - 2019}

pendekatan Neo-Merkantilisme menekankan pada perlindungan industri dalam negeri melalui kebijakan pemerintah yang bersifat proteksionis. ${ }^{12}$ Kebijakan proteksionisme sendiri bertujuan guna melindungi usaha domestik dan mempertahankan kepentingan nasional dalam bidang ekonomi. Salah satu bentuk perlindungan tersebut adalah menetapkan Non-Tariff Barriers (NTBs) atau yang lebih dikenal dengan hambatan nontarif dalam perdagangan. ${ }^{13}$

NTBs merupakan salah satu hambatan perdagangan dimana pemerintah dalam sebuah negara menetapkan kebijakan dalam membatasi masuknya barang-barang impor melalui bentuk kuota, pembatasan terkait standar kesehatan dan keamanan suatu produk, khususnya produk berbasis agrikultur. ${ }^{14}$ Kebijakan NTBs sendiri terbagi atas 2 pembatasan utama: (1) Pembatasan Kuantitatif melalui sistem kuota dan Voluntary Export Restraint (VER) berupa pembatasan ekspor secara sukarela (2) Pembatasan Kualitatif (melalui standarisasi, kebijakan, maupun standar keamanan produk). ${ }^{15}$ Salah satu kebijakan NTBs yang masih diterapkan hingga tahun 2014 adalah penetapan kuota impor yang dilakukan oleh

\footnotetext{
${ }^{12}$ David N. Balaam and Michael Veseth, Introduction to Political Economy, Edisi Ketiga (New Jersey: Upper Saddle River, 2001), h. 27-30.

13 David N. Balaam and Bradford Dilman, Introduction to International Political Economy, Edisi Keenam (Boston: Pearson Education, 2014), h. 61-63.

${ }^{14}$ Andreas F. Lowenfeld, International Economic Law, Edisi Kedua (Oxford: Oxford University Press, 2008), h. 58.

${ }^{15}$ Bob Sugeng Hadiwinata, Politik Bisnis Internasional (Yogyakarta: Penerbit Kanisius, 2002), h. 65-69.
} 


\section{Jurnal Sentris KSMPMI Vol. 2 - 2019}

Amerika Serikat dan Uni Eropa terhadap produk-produk agrikultur guna melindungi industri pangan domestik. ${ }^{16}$

Selain Neo-Merkantilisme, penulis turut menggunakan kerangka pemikiran berupa konsep Kepentingan Nasional. Konsep ini diperlukan guna melihat respon Indonesia pasca kebijakan RED yang mengakibatkan terjadinya hambatan ekspor CPO ke Uni Eropa. Dalam paper ini, analisis terkait kepentingan nasional difokuskan pada aspek kepentingan ekonomi ndonesia terhadap CPO. Jika ditelaah, Kepentingan Nasional merupakan sebuah konsep yang memiliki multi-interpretasi, dimana kata 'nasional' seringkali merujuk pada pengertian negara sebagai aktor hubungan internasional. Kepentingan Nasional seringkali digunakan dalam Decision Making Process pada sebuah analisa terkait kebijakan luar negeri dari suatu negara, juga digunakan untuk mempertahankan power, kekayaan, ideologi, dan pandangan politik negara. ${ }^{17}$

Konsep ini kemudian ditekankan oleh Nuechterlein ke dalam beberapa definisi penting. Pertama, keinginan negara dalam mencapai sebuah tujuan yang diimplementasikan dalam pengambilan keputusan terkait dengan isu tertentu. Kedua, kedaulatan negara (independent sovereign states) karena hal ini berhubungan dengan penggunaan kekuatan (power) untuk meminta adanya larangan perdagangan ataupun penandatanganan perjanjian terkait dengan aliansi. Ketiga, diperlukan untuk penggambaran hubungan internal dan eksternal yang terjadi dalam

\footnotetext{
${ }^{16}$ Op.cit., Balaam and Dilman, Introduction to International Political Economy, Edisi Keenam, h. 63.

17 Joseph Frankel, Key Concepts in Political Sciences: National Interest (London: Palgrave Macmillan - Pall Mall Press Ltd., 1970), h. 15, 17-20.
} 
Jurnal Sentris KSMPMI Vol. 2 - 2019

suatu negara, maupun kepentingan publik terkait sebuah isu yang muncul dalam suatu negara nantinya. Dalam menganalisis hambatan ekspor CPO Indonesia ke Uni Eropa, penulis akan menggunakan 4 basis kepentingan nasional Nuechterlein: Kepentingan Pertahanan (Defense), Kepentingan Ekonomi, Kepentingan Tatanan Dunia (World Order Interest), dan Kepentingan Ideologi. Melalui 4 basis kepentingan nasional tersebut, tulisan ini akan difokuskan pada basis kepentingan ekonomi. Kepentingan ekonomi negara sendiri diperlukan guna meningkatkan kesejahteraan, relasi, dan kerjasama dengan negara lain. ${ }^{18}$

\section{Analisis}

Sejak tahun 2000-an, sejumlah negara berusaha untuk mengembangkan EBT untuk mencapai ketahanan energi karena terjadinya fluktuasi harga minyak mentah dunia, meningkatnya permintaan energi, dan adanya perhatian khusus terkait dampak bahan bakar fosil terhadap perubahan iklim global. Sejumlah negara seperti Amerika Serikat, Uni Eropa, Brazil, India, dan Tiongkok berusaha mengembangkan EBT melalui bentuk bioenergi yang kemudian ditransformasikan ke dalam model biofuel. Keadaan ini pada akhirnya meningkatkan permintaan negara-negara tersebut akan CPO produksi Indonesia. Terkait dengan hal ini, Indonesia telah memiliki kepentingan nasional terkait aspek ekonomi. Meningkatnya permintaan CPO berpengaruh langsung terhadap

18 Donald E. Nuechterlein, "National interests and foreign policy: A conceptual framework for analysis and decision-making," Britain Journal of International Studies Vol. 2 (1976): 246-248. 
Jurnal Sentris KSMPMI Vol. 2 - 2019

peningkatan neraca perdagangan Indonesia khususnya dalam kegiatan ekspor. $^{19}$

Akan tetapi, kegiatan ekspor CPO mengalami hambatan untuk memasuki pangsa pasar Uni Eropa pasca keluarnya kebijakan RED di tahun 2009. Dalam RED, mekanisme yang telah diterapkan dalam Directive 2009/28/EC menetapkan bahwa di tahun 2020 negara-negara anggota Uni Eropa harus mencapai target minimal sebesar 20\% dalam penggunaan EBT. Kebijakan ini bertujuan untuk meningkatkan efektivitas penggunaan energi berbasis low-carbon, memastikan bahwa ketahanan energi di kawasan Uni Eropa selalu terjaga, mengurangi polusi udara dengan mengurangi emisi gas, dan mengurangi dampak perubahan iklim. ${ }^{20}$ Di samping kebijakan tersebut, RED 2009 turut menetapkan target minimal $10 \%$ dalam penggunaan EBT dalam aspek transportasi, khususnya biofuel. ${ }^{21}$

Menilik pada RED melalui target penggunaan minimal sebesar $20 \%$ secara general dan $10 \%$ untuk transportasi bagi anggota Uni Eropa, beberapa negara telah memanfaatkan Crude Palm Oil (CPO) guna memenuhi kebutuhan biofuel dan biodiesel. Namun, keluarnya Renewable

19 Krystof Obidzinski, Rubeta Andriani, Heru Komarudin, and Agus Andrianto, "Environmental and Social Impacts of Oil Palm Plantations and their Implications for Biofuel Production in Indonesia," Ecology and Society Vol. 17 No. 1 Art. 25 (2012): 1.

${ }^{20}$ Natàlia Caldés, Pablo del Río, Yolanda Lechón, and Agime Gerbeti, "Renewable Energy Cooperation in Europe: What Next? Drivers and Barriers to the Use of Cooperation Mechanisms," Energies Vol. 12 Iss. 1 (2019): 1-3.

21 Kristina Wittkopp, Stephanie Ghislain, Perrine Fournier, and Karin Ulmer, PLANTING THE FOREST AT THE ROOT OF THE EU-INDONESIA TRADE RELATIONSHIP, Human Rights, Biodiversity and Forests: The Cornerstones of A 21st Century Free Trade Agreement (Brussels: ACT Alliance EU, 2018), h. 6-7. 
Jurnal Sentris KSMPMI Vol. 2 - 2019

Energy Directive (RED) Uni Eropa menimbulkan permasalahan tersendiri akan pemanfaatan Crude Palm Oil (CPO). Hal ini dikarenakan dalam Directive 2009/28/EC, Uni Eropa telah menetapkan kriteria atas biofuel melalui standar directive tersebut. Standarisasi ini meliputi beberapa hal. Pertama, Produksi biofuel harus bersifat berkelanjutan melalui kriteria yang ditetapkan oleh European Commission. Kedua, kriteria berkelanjutan dalam biofuel turut mengikutsertakan penggunaan bioliquids dalam pemanas ataupun tenaga listrik. Ketiga, produksi ataupun bahan baku biofuel tidak boleh merusak lahan yang digunakan dalam perlindungan biodiversitas yang berasal dari area hutan primer (khususnya tempat spesies asli tumbuhan), hutan lindung, padang rumput, lahan dengan cadangan karbon yang tinggi, dan lahan gambut. Keempat, produksi biofuel harus dilakukan secara ramah lingkungan dengan standar minimal $35 \%$ penghematan gas emisi. ${ }^{22}$

Adanya kriteria dasar dalam produksi biofuel yang ditetapkan Uni Eropa melalui RED mempengaruhi kegiatan ekspor CPO di Indonesia. Hal ini disebabkan anggapan Uni Eropa bahwa produksi CPO Indonesia tidak ramah lingkungan. Pandangan ini benar adanya, dikarenakan produksi biofuel Indonesia yang berasal dari CPO dilakukan dengan menebang hutan guna memudahkan penanaman kelapa sawit. Deforestasi hutan Indonesia dianggap merusak ekosistem serta keragaman flora dan fauna yang dimiliki Indonesia. Selain itu, deforestasi turut mengakibatkan

\footnotetext{
22 European Commission, "DIRECTIVE 2009/28/EC OF THE EUROPEAN PARLIAMENT AND OF THE COUNCIL of 23 April 2009 on the promotion of the use of energy from renewable sources and amending and subsequently repealing Directives 2001/77/EC and 2003/30/EC," European Union Law (Strasbourg: European Union, 2009).
} 
Jurnal Sentris KSMPMI Vol. 2 - 2019

peningkatan gas emisi yang menyebabkan Indonesia merupakan negara ke-3 terbesar penghasil emisi karbon di dunia setelah Amerika Serikat dan Tiongkok. Di samping itu, kerusakan hutan turut menyebabkan kelangkaan spesies. ${ }^{23}$

Penemuan beberapa fakta tersebut mengakibatkan terjadinya hambatan ekspor produk Crude Palm Oil (CPO) produksi Indonesia ke Uni Eropa mengalami fluktuasi yang cukup signifikan pasca berlakunya Renewable Energy Directive (RED) di tahun 2009. Dalam tulisan, penulis turut memaparkan tabel di bawah ini yang akan menggambarkan fluktuasi ekspor CPO dari Indonesia ke Uni Eropa sebelum dan sesudah diberlakukannya RED.

Tabel 1: Volume Ekspor Crude Palm Oil Indonesia ke Uni Eropa tahun 2008 - 2012 dalam bentuk ton

\begin{tabular}{|c|c|c|c|c|c|}
\hline Negara & 2008 & 2009 & 2010 & 2011 & 2012 \\
\hline Denmark & 14.984 .999 & 28.636 .577 & 10.787 .904 & 18.244 .960 & 13.252 .123 \\
\hline Jerman & 404.771 .561 & 461.450 .345 & 379.329 .724 & 263.555 .103 & 219.483 .521 \\
\hline Belanda & 1.295 .880 .637 & 1.364 .300 .391 & 1.197 .290 .358 & 873.038 .356 & 1.358 .254 .413 \\
\hline Swedia & 24.701 .798 & 33.771 .603 & 5.608 .874 & 5.691 .638 & 8.413 .878 \\
\hline
\end{tabular}

23 Richard L. Ottinger and Steven E. Miller, "Bioenergy in Developing Countries: Potential and Risks," Renewable Energy Law and Policy Vol. 1, Iss. 1 (2010): 28. 
Jurnal Sentris KSMPMI Vol. 2 - 2019

Sumber: UN COMTRADE (United Nations International Trade Statistic Database) melalui pengolahan. ${ }^{24}$

Melalui data yang penulis paparkan melalui tabel, penulis melihat bahwa fluktuasi ekspor CPO Indonesia terjadi sejak tahun 2010 yang disebabkan oleh adanya hambatan ekspor berupa standar produksi biofuel yang telah ditetapkan Uni Eropa kepada Indonesia. Hal ini pada akhirnya menjadikan Indonesia menetapkan standar keberlanjutan pengelolaan dan produksi CPO dalam bentuk The Indonesian Sustainable Palm Oil (ISPO) pada tahun 2011. ISPO merupakan sebuah aturan wajib terkait pengelolaan kelapa sawit yang bersifat berkelanjutan. Adanya ISPO merupakan satu hal yang penting, dikarenakan kelapa sawit merupakan salah satu komoditi unggulan Indonesia di bidang agrikultur yang memiliki peranan strategis dalam perekonomian Indonesia, khususnya kegiatan ekspor. ${ }^{25}$

Meskipun telah dicanangkan aturan ke dalam bentuk ISPO dan mengalami pembaharuan oleh Kementerian Pertanian Republik Indonesia tahun 2015, jalan menuju pengolahan sawit yang berkelanjutan tidak mudah. Dalam laporannya, Forest Watch Indonesia (FWI) mengungkapkan bahwa penerapan ISPO ternyata belum mampu dalam menanggulangi dampak negatif dari pengelolaan kelapa sawit hingga tahun 2017. Hal ini terjadi, akibat sulitnya perbaikan tata kelola

\footnotetext{
${ }^{24}$ UN COMTRADE, “Get Data: 1511 - Palm oil and its fractions; whether or not refined, but not chemically modified," United Nations International Trade Statistic Database, diakses: 5 Mei 2019, situs web: https://comtrade.un.org/data/

${ }^{25}$ Rusli Anwar, Santun R.P. Sitorus, Anas Miftah Fauzi, Widiatmaka, and Machfud, "PENCAPAIAN STANDAR INDONESIAN SUSTAINABLE PALM OIL (ISPO) DALAM PENGELOLAAN PERKEBUNAN KELAPA SAWIT DI KALIMANTAN TIMUR," Jurnal Littri Vol. 22 No. 1 (2016): 11-12.
} 
Jurnal Sentris KSMPMI Vol. 2 - 2019

perkebunan kelapa sawit, banyaknya tuntutan akan prinsip-prinsip berkelanjutan, dan timbulnya permasalahan terkait dengan Hak Asasi Manusia bagi para pekerjanya. Selain itu, sulitnya penanggulangan turut didukung dengan kajian Center for International Forestry Research (CIFOR) yang mengungkapkan bahwa produksi CPO sendiri berasal dari deforestasi hutan Indonesia. Deforestasi sendiri didukung dengan kurangnya perhatian pengusaha kelapa sawit terhadap pentingnya sertifikasi ISPO. Berdasarkan data, dari 11,6 juta hektar luas total perkebunan kelapa sawit di Indonesia, hanya ada 1,5 juta hektar area yang telah berupaya menerapkan prinsip keberlanjutan di bawah sistem ISPO. ${ }^{26}$

Kesulitan dalam penerapan ISPO terus berlanjut hingga tahun 2016. FWI memaparkan bahwa sejumlah perusahaan kelapa sawit di Indonesia masih melakukan kegiatan penanaman di lahan konservasi serta melanggar kaidah konservasi tanah dan air dalam proses pembukaan lahan kelapa sawit. Bahkan, sejumlah perusahaan turut melakukan penanaman kelapa sawit di lahan yang menjadi area konservasi adat bagi masyarakat setempat. Selain deforestasi hutan, penanaman kelapa sawit secara besarbesaran pun seringkali menyebabkan terjadinya kebakaran hutan dan lahan, kerusakan lahan gambut, konflik sosial-masyarakat (dengan perusahaan sawit setempat), pengrusakkan akibat tingginya penggunaan bahan-bahan kimia (pestisida, herbisida), dan timbulnya ancaman terhadap satwa liar yang dilindungi pemerintah. ${ }^{27}$

\footnotetext{
${ }^{26}$ Forest Watch Indonesia (FWI), 6 (ENAM) TAHUN ISPO: Kajian terkait Penguatan Instrumen ISPO dalam Merespon Dampak-dampak Negatif SEPERTI DEFORESTASI, KERUSAKAN EKOSISTEM GAMBUT, KEBAKARAN HUTAN DAN LAHAN, SERTA KONFLIK TENURIAL (Bogor: Forest Watch Indonesia, 2017), h. 1-7.

${ }^{27}$ Ibid., h. 33-50.
} 
Jurnal Sentris KSMPMI Vol. 2 - 2019

Permasalahan terkait produksi dan pengelolaan kelapa sawit yang dipaparkan FWI yang menyebabkan terjadinya hambatan ekspor CPO produksi Indonesia ke Uni Eropa hingga tahun 2015. Hambatan perdagangan sendiri mengakibatkan jatuhnya harga CPO di level terendah dalam pasar global pada tahun 2015, yaitu di bawah US\$ 600 per-metrik ton. Namun, jatuhnya harga CPO global tidak serta-merta mendongkrak volume ekspor CPO Indonesia ke Uni Eropa. Hal ini disebabkan oleh Uni Eropa, sebagai negara importir terbesar Indonesia, memiliki daya beli yang lemah terhadap CPO. ${ }^{28}$ Selain pembatasan impor, permasalahan terkait produksi dan pengelolaan kelapa sawit turut mengakibatkan masuknya CPO ke dalam daftar produk tidak ramah lingkungan di Perancis dan Jerman. Di samping itu, Russia pun turut melakukan larangan masuknya CPO Indonesia akibat keberadaan kadar peroksida di dalam CPO sebesar $0,9 \%{ }^{29}$

Penolakkan Crude Palm Oil (CPO) yang terus-menerus terjadi mengakibatkan Indonesia berusaha meyakinkan pihak Uni Eropa bahwa Crude Palm Oil (CPO) merupakan sumber Energi Baru dan Terbarukan (EBT) yang layak digunakan sesuai standarisasi RED. Hal ini dilakukan, karena Indonesia memiliki Kepentingan Nasional dalam basis Kepentingan Ekonomi. Pertama, Indonesia menganggap bahwa kelapa sawit merupakan sektor strategis perekonomian Indonesia, khususnya

\footnotetext{
${ }^{28}$ Tempo.co, "Harga CPO Jatuh di Level Terendah, Ekspor Indonesia Stagnan," TEMPO, 16 September 2015, diakses: 6 Mei 2019, situs web: https://bisnis.tempo.co/read/701216/harga-cpo-jatuh-di-level-terendah-eksporindonesia-stagnan/full\&view $=$ ok

29 Tempo.co, “CPO Dicekal Rusia, RI Siap Banding," TEMPO, 8 September 2014, diakses: 6 Mei 2019, situs web: https://bisnis.tempo.co/read/605305/cpo-dicekal-rusia-risiap-banding
} 
Jurnal Sentris KSMPMI Vol. 2 - 2019

terkait dengan bahan mentah. Kedua, perkembangan lahan kelapa sawit telah meningkatkan pembangunan ekonomi Indonesia. Ketiga, kelapa sawit merupakan komoditas ekspor terbesar di Indonesia. Hal ini dibuktikan melalui penelitian yang mengungkapkan bahwa di tahun 2007, nilai ekspor kelapa sawit telah mencapai 7.8 juta dollar Amerika Serikat. Angka ini telah mengalami peningkatan sebesar 6,9\% jika dibandingkan dengan tahun 2003 yang hanya mencapai 4\%. Bahkan, melalui angka ini, Indonesia telah berhasil menjadi produsen terbesar kelapa sawit pada tahun 2007 dengan produksi akhir mencapai 18.3 juta ton per-tahunnya. ${ }^{30}$

Akan tetapi, seluruh upaya yang telah dilakukan oleh Indonesia, baik melalui jalur ISPO, diplomasi, negosiasi, maupun perbaikan dalam produksi dan pengelolaan kelapa sawit, tidak disambut baik oleh Uni Eropa. Hambatan dagang tetap dijalankan dengan mempersulit masuknya CPO ke dalam pasar negara-negara anggota Uni Eropa. Kondisi ini dijalankan, karena masing-masing anggota Uni Eropa memiliki kepentingan nasional terkait penggunaan produk nabati. Pertama, Perancis dan Hungaria merupakan kedua produsen terbesar minyak yang berasal dari bunga matahari. Kedua, Jerman merupakan penghasil minyak rappessed terbesar di kawasan Uni Eropa dengan total produksi sebesar 30\%. Ketiga, sebagian besar anggota Uni Eropa telah menggunakan minyak kedelai sebagai salah satu bentuk energi berbasis nabati guna memenuhi kebutuhan industri pangan, non-pangan, maupun pemakaian rumah tangga di wilayah setempat. Keempat, Uni Eropa menganggap bahwa proses yang dilakukan Indonesia melalui ISPO tidaklah cukup.

\footnotetext{
${ }^{30}$ Amzul Rifin, “The Effect of Export Tax on Indonesia's Crude Palm Oil (CPO) Export Competitiveness,” ASEAN Economic Bulletin Vol. 27 No. 2 (2010): 173-174.
} 
Jurnal Sentris KSMPMI Vol. 2 - 2019

Indonesia harus menempuh sertifikasi Certified Sustainable Palm Oil (CSPO) yang berasal dari Roundtable on Sustainable Palm Oil (RSPO) yang disyaratkan oleh Uni Eropa. ${ }^{31}$

Kepentingan-kepentingan tersebut merupakan salah satu alasan Uni Eropa tetap menghambat masuknya CPO asal Indonesia ke Uni Eropa. Tidak sekedar menghambat masuknya CPO, Uni Eropa juga memperbarui peraturan terkait produksi biofuel dan biodiesel yang ramah lingkungan dengan mengeluarkan RED II pada tahun 2018. Dalam RED II, Uni Eropa melakukan 4 (empat) revisi terkait dengan komitmen penggunaan EBT bagi negara-negara anggotanya. Pertama, kriteria biofuel yang harus bersifat berkelanjutan dan tetap menjaga ekosistem serta keanekaragaman hayati setempat. Kedua, penggunaan energi tetap pada koridor pengurangan gas emisi karbon yang mengacu pada Paris Agreement. Ketiga, Uni Eropa mengisyaratkan penggunaan listrik berbasis EBT guna pemenuhan target regional sebesar 32\%. Keempat, pada tahun 2030, negara-negara anggota Uni Eropa tidak diperbolehkan untuk memanfaatkan biodiesel yang berasal dari CPO. ${ }^{32}$

Adanya amanden RED II pada akhirnya meningkatkan terjadinya hambatan ekspor CPO Indonesia ke Uni Eropa hingga awal tahun 2019. Hal ini disebabkan adanya persetujuan dari negara-negara anggota Uni

\footnotetext{
31 Adelita Sukma Kusumaningtyas, "Upaya Hambatan Non-Tarif Oleh Uni Eropa Terhadap Minyak Kelapa Sawit Indonesia," Jurnal Analisis Hubungan Internasional Vol. 6 No. 2 (2017): 150-153.

32 European Commission, "DIRECTIVE 2018/2001 OF THE EUROPEAN PARLIAMENT AND OF THE COUNCIL of 11 December 2018 on the promotion of the use of energy from renewable sources (recast)," European Union Law (Strasbourg: European Union, 2018).
} 
Jurnal Sentris KSMPMI Vol. 2 - 2019

Eropa untuk memasukkan kelapa sawit sebagai kategori bahan baku yang bersifat tidak berkelanjutan sebagai upaya untuk menjaga kelestarian lingkungan. Terkait dengan hambatan non-tarif ini, Indonesia mengungkapkan bahwa kelapa sawit Indonesia mengalami diskriminasi untuk memasuki wilayah Uni Eropa, dimana Indonesia membandingkan dengan produk bunga matahari dan rapeseed yang serupa dengan kelapa sawit. ${ }^{33}$ Selain itu, perekonomian Indonesia akan mengalami penurunan neraca perdagangan jika ekspor CPO dilarang oleh Uni Eropa. Bahkan, di awal tahun 2019, Indonesia telah mempersiapkan draf agar dapat menjadikan hal ini sebagai 'perkara' dalam WTO) dan menuntut Uni Eropa di dalamnya. ${ }^{34}$

\section{Kesimpulan}

Tulisan ini telah menjawab pertanyaan penelitian penulis yaitu: "Bagaimana terjadinya hambatan ekspor Crude Palm Oil (CPO) Indonesia ke Uni Eropa pasca Kebijakan Renewable Energy Directive (RED) berjalan?." Dalam paper ini, penulis menggunakan 2 (dua) kerangka pemikiran guna menjawab pertanyaan penelitian, yaitu Teori Neo-Merkantilisme terkait Hambatan Non-Tarif dan Konsep Kepentingan Nasional guna melihat kepentingan Indonesia maupun negara-negara

\footnotetext{
${ }^{33} \mathrm{BBC}$ Indonesia, "Kelapa sawit, ancaman perang dagang RI-Uni Eropa dan enam hal lainnya," BBC Indonesia, 23 Maret 2019, diakses: 7 Mei 2019, situs web: https://www.bbc.com/indonesia/indonesia-47663602

${ }^{34}$ CNN Indonesia, "Indonesia akan Lawan Diskriminasi Sawit Uni Eropa ke WTO,” CNN Indonesia, 18 Maret 2019, diakses: 7 Mei 2019, situs web: https://www.cnnindonesia.com/ekonomi/20190318183118-92-378457/indonesia-akanlawan-diskriminasi-sawit-uni-eropa-ke-wto
} 
Jurnal Sentris KSMPMI Vol. 2 - 2019

anggota Uni Eropa dalam melihat terjadinya hambatan perdagangan CPO ini. Hambatan ekspor CPO Indonesia ke Uni Eropa bermula sejak penetapan RED berupa Directive 2009/28/EC yang ditandatangani pada 23 April 2009.

RED sendiri merupakan kebijakan Uni Eropa dalam penggunaan EBT, khususnya biofuel dan biodiesel yang bersifat berkelanjutan baik dalam proses produksi maupun pengelolaannya. Poin Directive yang ditetapkan tahun 2009 pada akhirnya mengakibatkan terjadinya hambatan ekspor CPO sejak 2010. Uni Eropa melakukan hal ini, dikarenakan CPO yang berasal dari Indonesia tidak memenuhi standarisasi berkelanjutan seperti yang mereka tetapkan. Akan tetapi, Indonesia tidak putus asa dan terus memperjuangkan agar $\mathrm{CPO}$ dapat diterima di pasar Uni Eropa. Dalam hal ini, Indonesia mengupayakan pelaksanaan ISPO guna memenuhi syarat berkelanjutan dalam produksi CPO Indonesia. Perjuangan Indonesia terkait dengan kelapa sawit terkait langsung dengan kepentingan nasional Indonesia dalam aspek ekonomi. Indonesia berpendapat, bahwa kelapa sawit merupakan sektor strategis perekonomian Indonesia, khususnya terkait dengan aspek pembangunan ekonomi dan peningkatan neraca dagang ekspor.

Meskipun telah ditetapkan ISPO, akan tetapi pelaksanannya kurang efektif. Hal ini disebabkan oleh pelanggaran aturan penanaman, konservasi lahan, tumpang-tindihnya aturan hukum, hingga terjadinya permasalahan terkait dengan tanah adat. Uni Eropa tetap tidak menganggap bahwa kelapa sawit merupakan salah satu produk yang bersifat berkelanjutan, dikarenakan tidak adanya sertifikasi RSPO. Di samping itu, permasalahan CPO terkait langsung dengan kepentingan 
Jurnal Sentris KSMPMI Vol. 2 - 2019

nasional masing-masing negara Eropa, khususnya Perancis dan Hungaria (bunga matahari) serta Jerman (rapeseed) dalam pengelolaan bahan nabati. Kepentingan Nasional ketiga negara tersebut pada akhirnya melahirkan RED II tahun 2018, dimana kebijakan ini turut menjadikan hambatan ekspor CPO Indonesia terus berlanjut hingga awal tahun 2019. 
Jurnal Sentris KSMPMI Vol. 2 - 2019

DAFTAR PUSTAKA

\section{$\underline{\text { BUKU }}$}

Balaam, David N. and Bradford Dilman. Introduction to International Political Economy:

Sixth Edition. Boston: Pearson Education, 2014.

Balaam, David N. and Michael Veseth, Introduction to Political Economy: Third Edition.

New Jersey: Upper Saddle River, 2001.

Dalby, Simon. "Climate Change and Environmental Security," In Security Studies: An

Introduction, Second Edition, edited by Paul D. Williams, 311-323. Oxon: Routledge,

2013.

Frankel, Joseph. Key Concepts in Political Sciences: National Interest. London: Palgrave

Macmillan - Pall Mall Press Ltd., 1970.

Hadiwinata, Bob Sugeng. Politik Bisnis Internasional. Yogyakarta: Penerbit Kanisius, 2002.

Haynes, Jeffrey, Peter Hough, Shahin Malik, and Lloyd Pettiford. World Politics. Oxon:

Routledge, 2013. 
Jurnal Sentris KSMPMI Vol. 2 - 2019

Hiscock, Geoff. "Earth Wars: The Battle for Global Resources." Singapore: Wiley, 2012.

Kerr, Pauline. "Human Security," In Contemporary Security Studies, Third Edition, edited by

Alan Collins, 104-116. Oxford: Oxford University Press, 2013.

Lowenfeld, Andreas F. International Economic Law: Second Edition. Oxford: Oxford

University Press, 2008.

\section{DOKUMEN UNI EROPA}

European Commission. "DIRECTIVE 2009/28/EC OF THE EUROPEAN PARLIAMENT

AND OF THE COUNCIL of 23 April 2009 on the promotion of the use of energy

from renewable sources and amending and subsequently repealing Directives

2001/77/EC and 2003/30/EC." European Union Law. Strasbourg: European Union,

2009.

European Commission. “DIRECTIVE 2018/2001 OF THE EUROPEAN PARLIAMENT 
Jurnal Sentris KSMPMI Vol. 2 - 2019

AND OF THE COUNCIL of 11 December 2018 on the promotion of the use of

energy from renewable sources (recast)." European Union Law.

Strasbourg:

European Union, 2018.

European Union. European Commission (EC) - Eurostat. Renewable Energy Statistic:

Statistics Explained. Brussels, 2019.

\section{JURNAL}

Anwar, Rusli, Santun R.P. Sitorus, Anas Miftah Fauzi, Widiatmaka, and Machfud.

"PENCAPAIAN STANDAR INDONESIAN SUSTAINABLE PALM OIL (ISPO)

DALAM PENGELOLAAN PERKEBUNAN KELAPA SAWIT DI KALIMANTAN TIMUR.” Jurnal Littri Vol. 22 No. 1 (2016): 11-18.

Caldes, Natalia, Pablo de Rio, Yolanda Lechon, and Agime Gerbeti. "Renewable Energy

Cooperation in Europe: What Next? Drivers and Barriers to the Use of Cooperation Mechanisms.” Energies Vol. 12 Iss. 1 (2019): 1-22. 
Jurnal Sentris KSMPMI Vol. 2 - 2019

Khairunisa, Gisa Rachma dan Tanti Novianti. "DAYA SAING MINYAK SAWIT DAN

DAMPAK RENEWABLE ENERGY DIRECTIVE (RED) UNI

EROPA

TERHADAP EKSPOR INDONESIA DI PASAR UNI EROPA.”

Jurnal Agribisnis Indonesia Vol. 5 No. 2 (2017): 125-136.

Kusumaningtyas, Adelita Sukma. "Upaya Hambatan Non-Tarif Oleh Uni Eropa Terhadap

Minyak Kelapa Sawit Indonesia." Jurnal Analisis Hubungan Internasional Vol. 6 No. 2 (2017): 148-161.

Nuechterlein, Donald E. "National interests and foreign policy: A conceptual framework for

analysis and decision-making." Britain Journal of International Studies Vol. 2 (1976): 246-266.

Obidzinski, Krystof, Rubeta Andriani, Heru Komarudin, and Agus Andrianto. "Environmental

and Social Impacts of Oil Palm Plantations and their Implications for Biofuel Production in Indonesia." Ecology and Society Vol. 17 No. 1 Art. 25 (2012): 1-19.

Ottinger, Richard L. and Steven E. Miller. "Bioenergy in Developing Countries: Potential and 
Jurnal Sentris KSMPMI Vol. 2 - 2019

Risks." Renewable Energy Law and Policy Vol. 1, Iss. 1 (2010):

23-32.

Rifin, Amzul. "The Effect of Export Tax on Indonesia's Crude Palm Oil (CPO) Export

Competitiveness.” ASEAN Economic Bulletin Vol. 27 No. 2 (2010): 173-184.

\section{LAPORAN DAN PUBLIKASI}

Forest Watch Indonesia (FWI). 6 (ENAM) TAHUN ISPO: Kajian terkait Penguatan Instrumen ISPO dalam Merespon Dampak-dampak Negatif SEPERTI DEFORESTASI, KERUSAKAN EKOSISTEM GAMBUT, KEBAKARAN HUTAN DAN LAHAN, SERTA KONFLIK TENURIAL. Bogor: Forest Watch Indonesia, 2017.

Lee, Bernice, Felix Preston, Jaakko Kooroshy, Rob Bailey, and Glada Lahn (Chatnam House). Resources Futures: A Chatham House Report. London: The Royal Institute of International Affairs, 2012.

Lendle, Andreas and Malorie Schaus. Sustainability Criteria in the EU Renewable Energy

Directive: ICTSD Information Note No. 2, September 2010. Geneva: International

Center for Trade and Sustainable Development.

Sheil, Douglas. The Impacts and Opportunities of Oil Palm in Southeast Asia. Jakarta: Center 
Kelompok Studi Mahasiswa Pengkaji Masalah Internasional

Jurnal Sentris KSMPMI Vol. 2 - 2019

for International Forestry Research, 2009.

United States Department of Energy. Renewable Energy: An Overview. Golden, Colorado:

National Renewable Energy Laboratory (NREL), 2001.

Wittkopp, Kristina Stephanie Ghislain, Perrine Fournier, and Karin Ulmer. PLANTING THE

FOREST AT THE ROOT OF THE EU-INDONESIA TRADE RELATIONSHIP.

Human Rights, Biodiversity and Forests: The Cornerstones of A 21st Century Free

Trade Agreement. Brussels: ACT Alliance EU, 2018.

\section{$\underline{\text { SITUS WEB }}$}

BBC Indonesia. “Kelapa sawit, ancaman perang dagang RI-Uni Eropa dan enam hal lainnya." BBC Indonesia, 23 Maret 2019. Diakses: 7 Mei 2019, url: https://www.bbc.com/indonesia/indonesia-47663602

CNN Indonesia. "Indonesia akan Lawan Diskriminasi Sawit Uni Eropa ke WTO." CNN

Indonesia, 18 Maret 2019. Diakses: 7 Mei 2019, url:

https://www.cnnindonesia.com/ekonomi/20190318183118-92$\underline{378457 / \text { indonesia- }}$

akan-lawan-diskriminasi-sawit-uni-eropa-ke-wto 
Jurnal Sentris KSMPMI Vol. 2 - 2019

Tempo.co. “CPO Dicekal Rusia, RI Siap Banding.” TEMPO, 8 September 2014. Diakses:

6 Mei 2019, url:

https://bisnis.tempo.co/read/605305/cpo-dicekal-rusia-ri-siapbanding

Tempo.co. "Harga CPO Jatuh di Level Terendah, Ekspor Indonesia Stagnan." TEMPO,

16 September 2015. Diakses: 6 Mei 2019, situs web:

https://bisnis.tempo.co/read/701216/harga-cpo-jatuh-di-level-

terendah-ekspor-

indonesia-stagnan/full\&view $=$ ok

UN COMTRADE. “Get Data: 1511 - Palm oil and its fractions; whether or not refined, but not chemically modified." United Nations International Trade Statistic Database),

Diakses: 5 Mei 2019, situs web: https://comtrade.un.org/data/

\section{$\underline{\text { TESIS }}$}

Debora M., Retno Ayu. "PENOLAKAN CRUDE PALM OIL (CPO) INDONESIA OLEH UNI EROPA.” Tesis Magister Ilmu Hubungan Internasional, Universitas Gadjah Mada, Yogyakarta, 201 
